\title{
FRA ELEKTRONISKE KATALOGER TIL INFORMASJONSSYSTEM UTVIKLINGEN I BRUK AV INFORMASJONSTEKNOLOGI VED NORSKE MUSEER
}

Jon Birger Østby

I 1970-årene var museene primert opptatt av à standardisere og automatisere katalogene. Målgruppene var museets egne ansatte og fagkolleger ved andre institusjoner. I dag ligger hovedutfordringen $i$ à bruke Internett for à la nye målgrupper få tilgang til museenes kunnskaps-og opplevelseskilder.

\section{DE FØRSTE TILTAKENE}

NAVFs EDB-senter for humanistisk forskning i Bergen' ble opprettet i 1972 som et service- og utviklingsorgan for databehandling i de humanistiske fagene. I 1976 fikk registrator Randi M. Johannessen ved Norsk Folkemuseum et stipend til hospitantopphold ved Humanistisk datasenter. Oppholdet resulterte i et samarbeid om et prøveprosjekt på databehandling av gjenstandskatalogene ved Norsk Folkemuseum, og dette ble innledningen til et langvarig og fruktbart samarbeid mellom Humanistisk datasenter og de kulturhistoriske museene i Norge.

Den gang kunne man knapt ane hvor raskt utviklingen på datasiden skulle gå. Ingen museer hadde planer om å anskaffe eget datautstyr. Registreringskortet var utviklet slik at det både skulle kunne brukes i manuelle kataloger og ved optisk lesing for innlegging av data $\mathrm{i}$ tekstsøkesystemet Nova Status på Univac-maskinen ved Universitetet i Bergen. Kortene ble skrevet ut på museet, og det kunne gå både tre og fire runder med korrektur før resultatet av den optiske lesingen hadde gitt et akseptabelt resultat slik at Humanistisk datasenter kunne levere de $ø$ nskede utskriftene.

I 1979 ble den første nasjonale konferanse om datatjenester og datasamarbeid mellom de kunst- og kulturhistoriske museene arrangert. Konferansen befestet samarbeidet mellom Humanistisk datasenter og museumsmiljøet, og samme år la Norske Kunst- og Kulturhistoriske Museers (NKKMs) EDB-utvalg frem et forslag til katalogkort for registrering av kultur- 
20 historisk gjenstandsmateriale. Dette kortet ble et gjennombrudd $\mathrm{i}$ arbeidet for en felles standard for katalogisering ved de kulturhistoriske museene i Norge. Her var Norge tidlig ute. Jeg tror det var to årsaker til dette. For det første tok NKKM et sentralt ansvar for å styre denne utviklingen, og norske museer ble tilført en felles ressurs i de konsulenttjenestene som ble gitt gratis fra Humanistisk datasenter. I utlandet så vi hvordan store institusjoner var avhengig av å kjøpe konsulenthjelp på det private markedet, og at de ofte valgte forskjellige løsninger innenfor samme land. Ved NKKMs sterke engasjement i Norge fikk vi felles utviklingsprosjekter og felles standarder der man tok sterkt hensyn også til mindre institusjoner.

I gjenstandsfagene er den visuelle opplevelsen av materialet sentral. Men på slutten av 1970-tallet så man ingen snarlige løsninger for å få realisert bildedatabaser knyttet til gjenstandskatalogene. Noen hadde hørt at det skulle pågå forskning med elektronisk behandling av bilder innenfor det amerikanske forsvaret, men det norske katalogkortet bar preg av at man forsøkte å erstatte det visuelle inntrykket med en grundigere gjenstandsbeskrivelse enn det som hadde vært praksis tidligere. Vi var opptatt av å gi gjenstandene detaljerte beskrivelser for à kunne identifisere de enkelte objektene, og i ettertid er det lett å se at vi i utarbeidingen av katalogstandarden burde ha lagt enda større vekt på dokumentasjon av gjenstandenes historie og andre opplysninger som ikke kan leses ut fra gjenstanden selv.

\section{OM UTSTYRSSITUASJONEN}

Tidlig på 1980-tallet var det enda vanlig oppfatning at humanistiske forskere burde kunne klare seg med blyant og papir. Det var realister, teknologer og medisinere som hadde tradisjon for å få midler fra forskningsrådene til teknisk utstyr. Men også her fikk museene viktig støtte og bistand fra Humanistisk datasenter i kampen om midlene, både gjennom en generell dokumentasjon av behovene og ved hjelp til å formulere søknader. Utviklingen på datasiden kom til å gå langt raskere enn man hadde forutsett. I 1983 fikk Norsk Folkemuseum midler fra Norges forskningsråd til sin første datamaskin, en Altos minimaskin med 4 terminaler og et platelager på $8 \mathrm{Mb}$ ! På den tiden var det meget avansert å ha datamaskin med et fast platelager, og enda i mange år fram i tiden var det et klart krav fra museer å få levert programvare for gjenstands- og fotoregistrering som kunne håndteres på rene diskettmaskiner. Utstyret på denne tiden hadde en relativt langt høyere pris enn tilfellet er i dag. Til Norsk Folkemuseums første EDB-utstyr hørte en typehjulsskriver, Nec Spinwriter, som alene kostet $65.000 \mathrm{Nkr}$, og etter å ha investert Nkr 3.500 til en støydempende kasse kunne vi til nød sitte å arbeide i nabokontoret når skriveren var i bruk

Humanistisk datasenter arrangerte kurs i tekstbehandling og dataregistrering, og snart var det mange museer rundt om, også mindre museer, som fikk eget datautstyr. For egen del er jeg ikke i tvil om at den største forbedring jeg har opplevd i min arbeidssituasjon var å kunne flytte kontorstolen bort fra skrivemaskinen og til datatastaturet. 
1996 la det norske Kulturdepartementet fram dokumentet "Skape bevare formidle. Grunnlagsmateriale for en IT-plan for kultursektoren». Dette ble $i$ 1997 fulgt opp med en handlingsplan med samme titel. Et viktig resultat av dette vil vare

Kulturnett Norge, der museene tar del med sitt eget Museumsnett Norge.

\section{UTVIKLING AV FELLES REGISTRERINGSPROGRAM}

I 1984 startet Humanistisk datasenter et toårig EDB-prosjekt for kunst- og kulturhistoriske museer. Her skulle det blant annet utvikles et opplegg for registrering av gjenstander og fotografier for bruk på personlige datamaskiner plassert ved de

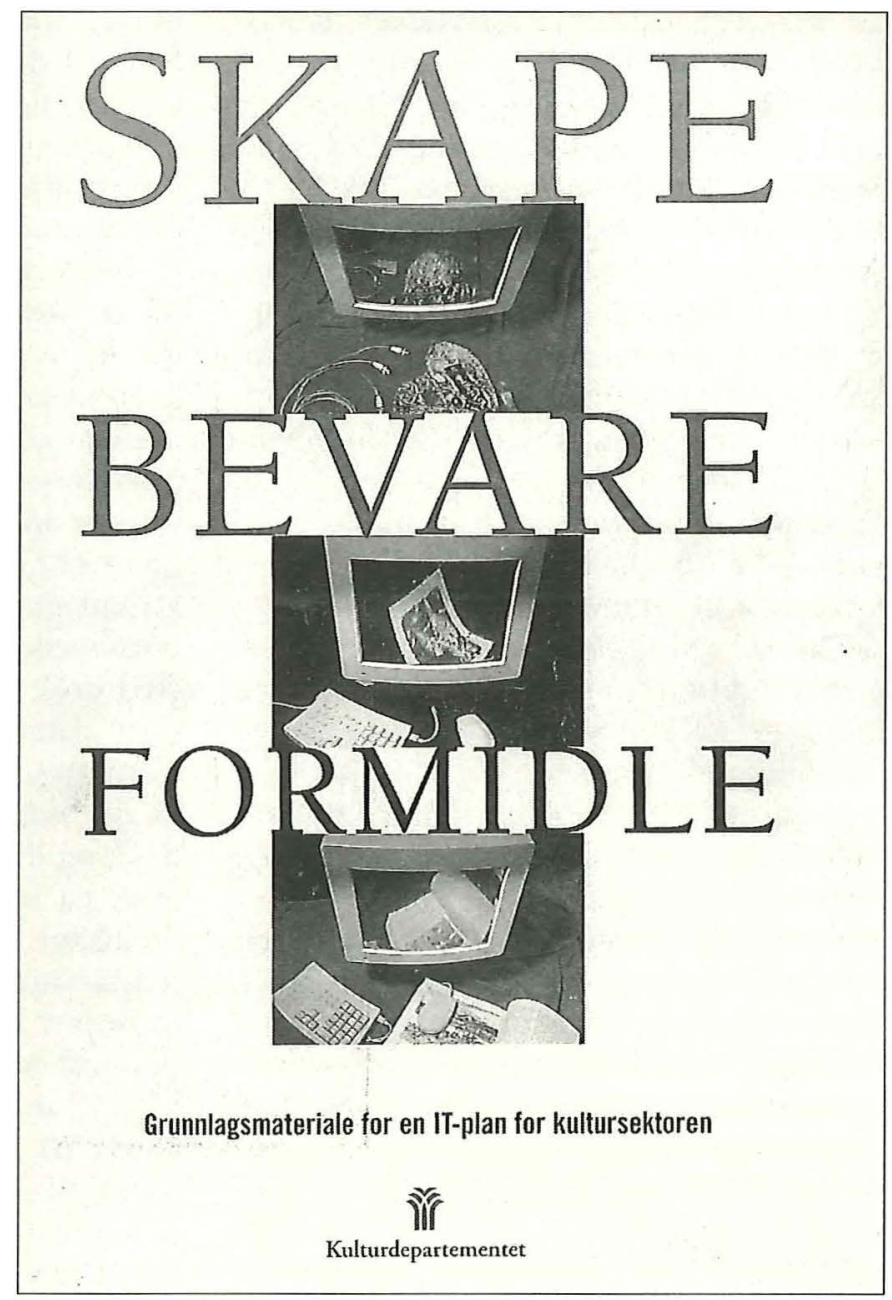

enkelte institusjonene. Feltstandardene tok utgangspunkt i gjenstandskortet fra 1977 og det kortet som Sekretariatet for fotoregistrering hadde utviklet for fotoregistrering. Oppleggene ble samordnet slik at felles data for gjenstander og fotografier fikk samme format.

Dette første opplegget ble så igjen revidert i 1991/92 i forbindelse med utvikling 
22 av det nye registreringssystemet REGIMUS som ble utviklet ved Humanistisk datasenter etter oppdrag fra NKKM og med midler fra Norsk kulturråd. I sammenheng med dette prosjektet fikk Norsk Folkemuseum i oppdrag å revidere feltstandarden. Den revisjonen som ble gjennomført, bygger på museets egne erfaringer med systemet og på en spørreundersøkelse til alle institusjoner som brukte oppleggene, for gjenstands- og/eller fotoregistrering. Samtidig ble det også utviklet en feltstandard for kunstindustriprodukter i samarbeid med Kunstindustrimuseet i Oslo, en feltstandard for billedkunst i samarbeid med Nasjonalgalleriet og et enkelt bibliotekopplegg for museer uten bibliotekfaglig personale i samarbeid med Riksbibliotektjenesten.

I dag er det ca 150 kulturhistoriske museer og andre institusjoner som bruker registreringsopplegg som er utviklet ved Humanistisk datasenter. Noen museer har imidlertid valgt å utvikle egne løsninger. Flere små museer har funnet å kunne spare penger ved å bruke billigere programvare kombinert med rimelig eller gratis dataekspertise. Mange museer har utnyttet sivilarbeidere med datakompetanse i slike prosjekt, men flere av disse har fått store problemer med oppfølging når denne kompetansen ikke lenger er tilgjengelig i institusjonen, f.eks. når sivilarbeideren slutter. En av fordelene ved å velge sentrale fellesløsninger vil alltid være at man har sikkerhet for at opplegget er tilpasset de gjeldende standarder, og at det vil bli utført et felles utviklingsarbeid for konvertering av data ved endringer av katalogstandarder eller overgang til ny programvare.

Universitetsmuseene har gjennom sine moderinstitusjoner hatt en annen tilgang både til datakompetanse og til datautstyr enn de fleste andre museene i Norge. I 1991 ble det etablert et stort dokumentasjonsprosjekt for å få lagt inn referanseopplysninger til universitetenes samlinger på språk og kultur, og i 1994 ble det startet et tilsvarende prosjekt for naturhistorie. Mens man innenfor de kulturhistoriske museene har vært svært opptatt av å utvikle felles standarder, har man i dokumentasjonsprosjektet for språk og kultur valgt et annet utgangspunkt. Her er dataene i stor grad registrert i den form de har i grunnlagsmaterialet. Tekst blir lest inn optisk eller tastet inn manuelt og tagget (ved bruk av SGML) i henhold til en formell datamodell. Særlig gjennom dokumentasjonsprosjektet for språk og kultur er det utført et betydelig registreringsarbeid, og deler av materialet er tilgjengeliggjort på Internett. Arbeidet er i stor grad finansiert gjennom arbeidsmarkedstiltak. Arbeidssituasjonen i Norge er vesentlig forbedret i de siste par år, og følgelig trappes arbeidsmarkedstiltakene ned. Som mange andre museumsprosjekter som er basert på slik finansiering, ser det derfor nå ut til at det blir vanskelig å føre prosjektet videre med samme styrke.

I 1993 tok Norsk museumsutvikling $(\mathrm{NMU})^{2}$ initiativ til et samarbeidsprosjekt BAUTA for utvikling av en prototyp for formidling av billedmateriale med tekstbaserte referanseopplysninger over Internett. Her deltok Institutt for datateknikk og telematikk ved Norges Tekniske Høgskole, Norsk Folkemuseum, Nasjonalbibliotekavdelinga i Rana, BIBSYS (fag- og forskningsbibliotekenes felles bibliotekdatabase), Universitetenes dokumentasjonsprosjekt for språk og kultur, Riksarkivet og 
NMU. Prosjektet ble avsluttet i 1995, men prototypen er videreutviklet og danner basis for billedatabasen Galleri Nord som drives av Nasjonalbiblioteket.

I samarbeidet mellom NKKM og Humanistisk datasenter har det hele tiden vært lagt stor vekt på å utvikle systemer som skal kunne anskaffes innenfor de økonomiske rammer som kan være realistiske også for mellomstore og mindre museer. I de senere årene har derfor større nasjonale museer sett behov for å utvikle større og mer kostbare systemer for å tilfredsstille egne behov. Nasjonalgalleriet har fått utviklet en egen database for kunstverk, mens Norsk Folkemuseum, Maihaugen, Norsk Teknisk Museum og Norsk Telemuseum har gått sammen om prosjektet PRIMUS. Formålet med PRIMUS er å utvikle et helhetlig informasjonssystem for registrering, administrasjon og presentasjon av museumssamlinger.

\section{DAGENS UTFORDRINGER}

Det er nå på tide å se hvordan vi igjen kan samle trådene for å sikre at vi i framtiden kan få en god og rasjonell utveksling og sambruk av data fra de forskjellige museene. På oppdrag fra NMU leder Nasjonalgalleriet og Norsk Folkemuseum et arbeid for å forsøke å samordne datastandarder for registrering av billedkunst og kulturhistorisk gjenstandsmateriale og fotografier, og det er en utfordring å se hvordan vi kan videreutvikle samarbeidet mellom PRIMUS-gruppen og de produktene som leveres fra Humanistisk datasenter. Ut året 2001 har datasenteret en øremerket bevilgning fra Norges forskningsråd til utviklingsarbeid for museumssektoren, men Senteret har varslet at etter at denne utløper, må museumssektoren selv overta hovedansvaret for dette feltet.

Samtidig står vi i dag på mange måter ved et skillepunkt i utviklingen av museenes EDB-bruk. Tidligere har vi primært vært opptatt av å utvikle datasystemer som skal håndtere museets egne interne behov. Museene skal tilpasse seg et publikum som har stadig bredere allmennutdannelse, og som har andre krav og forventninger enn tidligere generasjoner. Dagens publikum ønsker tilgang også til den del av museenes samlinger som ikke vises i utstillingene. Det betyr for det første at vi må arbeide for at de katalogene som opprinnelig er utarbeidet for å betjene museets eget fagpersonale, også skal kunne fungere i forhold til publikum, og vi må se på hvordan vi kan videreutvikle systemene slik at både fagpersonale og publikum kan bruke referansedata til gjenstander, fotosamlinger, arkiv og bibliotek i sammenheng.

For store deler av publikum vil katalogene ha begrenset verdi, og den største utfordringen ligger $\mathrm{i}$ å bruke de mulighetene som IT-teknologien gir til formidling over nettet. I dag regner vi at i overkant av $30 \%$ av den norske befolkningen har tilgang til Internett hjemme, på skole eller på arbeidsplassen. Det er viktig å sikre at hele befolkningen skal ha denne muligheten. Her peker folkebibliotekene seg ut som sentrale institusjoner. Mange folkebibliotek fungerer i dag som informasjonssentraler langt ut over den informasjonen som finnes i tradisjonelle trykte publikasjoner, og folkebibliotekene skal nå få terminaler som gir publikum tilgang til Internett. 
JON BIRGER ØSTBY

KULTURNETT NORGE - MUSEUMSNETT NORGE

For å møte denne utfordringen har Kulturdepartementet tatt initiativ til å skape et elektronisk knutepunkt for informasjon om norsk kulturtilbud gjennom Kulturnett Norge. I dette prosjektet blir det viktig å gi både inspirasjon og faglig hjelp til kunst- eller kulturmiljøer som ønsker å bruke Internett eller verdensveven for å nå ut til et bredere publikum.

Gjennom Kulturnettet skal både norske og utenlandske nettbrukere få anledning til å bli kjent med norsk kultur. Det er en sentral kulturpolitisk oppgave å sørge for at det særlig for ungdom skal ligge gode norske nett-tilbud som alternativ til alt det engelskspråklig materialet. Gode netttilbud er et viktig ledd i kampen mot amerikaniseringen, og det ser ut som kampen for norsk språk delvis vil måtte flyttes fra skolene til programvarehusene.

Tradisjonelt brukes det lite midler til opplæring og personalutvikling ved norske museer. Det utarbeides vedlikeholdsplaner for bygg og anlegg, museene inngår serviceavtaler for data- og sikringsanlegg, men planlegger museene tilsvarende måte for å opprettholde relevant kompetanse på personalsiden? Det ser ut til at dette er et område som i alt for stor grad er basert på den enkelte arbeidstakers egen ansvarsfølelse og initiativ. Formidling og kommunikasjon via nettet krever ny kunnskap og kompetanse i museene. Dette må dels løses ved opplæring av det eksisterende personalet og dels med nyrekruttering.

Vi trenger personale som kan bruke teknologien, og det museumsfaglige personalet må lære å kommunisere med teknologene. Den største utfordringen ligger tro- lig i å utvikle bedre kompetanse på kommunikasjon via elektroniske medier, og på dette feltet vil bli satt igang egne opplæringsprogram.

Bruk av Internett reiser en rekke nye opphavsrettslige spørsmål, og det vil være svært alvorlig om museenes nettformidling bare skal omfatte materiale der de økonomiske opphavsrettene er utløpt. Vi ser en tendens til stadig flere betalingstilbud på Nettet. Vi har i Norden en demokratisk tradisjon der fri tilgang til kunnskap og informasjon er sentrale elementer. Dette er en tradisjon som det er viktig å verne om, og det vil være svært alvorlig dersom museenes nettpresentasjoner skal måtte prises på et nivå som gjør at de primært betjener samfunnsgrupper eller institusjoner med sterk økonomi.

Så lenge katalogene kun har vært manuelle, har det vært relativt enkelt å føre tilsyn med tilgang og bruk, og mange museer har derfor tatt lett på spørsmål om personvern og etikk i forhold til dette materialet. Men når katalogene nå skal gjøres tilgjengelige for allmennheten er det en helt nødvendig forutsetning at de enkelte institusjonene foretar en grundig gjennomgang av materialet og fastsetter normer for hvilke data og hvilket materiale som skal beskyttes ut fra rettslige og etiske hensyn.

Internett åpner ikke bare nye kommunikasjonskanaler mellom museene og publikum. Det ligger også utfordringer i å bruke nettet som møteplass og samarbeidsforum mellom museumsmedarbeidere både på regionalt, nasjonalt og internasjonalt nivå.

I Kulturnett Norge skal det bygges opp egne sektornett for arkiv, bibliotek og museer. Ansvaret for museumsnettet er lagt til NMU. Målet er at Museumsnett Norge skal kunne være en innfallsport til 
alle de museumsrelaterte informasjons- og kunnskapskilder som er lagt ut på nettet. Museumsnett Norge skal betjenes fra en server som plasseres på Norsk Folkemuseum. De museene som selv ikke har nettilkobling eller som av sikkerhetsmessige årsaker ikke ønsker å slippe eksterne brukere inn på eget datanett, vil få tilbud om å legge ut hjemmesider og annet materiale på denne serveren. I utgangspunkt legges det opp til følgende hovedinndeling:

1. Museumsoversikt

2. Nettutstillinger

3. Søk i museenes samlinger

4. Skoleveien til museene

5. Forskning og dokumentasjon

6. Museumsfaglig informasjon

7. Veien videre ut

De første deler av Museumsnettet vil bli åpnet rundt årsskiftet 1997/98. Men det vil ta tid å bygge ut nett-tilbudet, og resultatet vil være helt avhengig av de prioriteringer og den innsats de enkelte museene vil legge i denne satsingen. Det ligger en særlig utfordring for nasjonale museer i å bruke nettet til å nå ut til publikum som på grunn av geografiske avstander ikke selv har anledning til å besøke museets utstillinger og arkiv.

Nedenfor vil jeg presentere noen av de planer og ideer som etter hvert skal gi Museumsnettet innhold:

\section{Museumsoversikt}

Her vil det legges ut en enkel oversikt over landets 800 museer og samlinger med: navn, geografisk plassering, adresse, telefon og faks, en til to fotografier og en kort omtale på norsk, engelsk, tysk og fransk. I utgangspunktet vil vi bygge på NMUs adressekatalog for museene og en illustrert museumsguide som er utgitt av museumsorganisasjonene. I tillegg vil det ligge pekere til musenes egne hjemmesider. Senere i prosjektet tar vi sikte på å legge ut sentrale tall fra den offisielle museumsstatistikken som: besøk, størrelse på samlinger, årsverk og totalt årlig budsjett. Det arbeides også med planer for et tilbud om en elektronisk meldingstjeneste der museene $\mathrm{i}$ framtiden selv skal kunne oppdatere opplysninger om åpningstider, utstillinger og andre arrangementer.

\section{Nettutstillinger}

Her vil publikum kunne finne både selvstendige utstillinger som er laget for nettet, og presentasjoner som er knyttet til utstillinger som vises $\mathrm{i}$ museene. Til åpningen skal det lages en Munch-utstilling $\mathrm{i}$ samarbeid med Nasjonalgalleriet. Munch er valgt for å presentere et utstillingstilbud som også har internasjonal interesse. Maihaugen har fått tilskudd til en nettpresentasjon som er knyttet til utstillingen "Langsomt ble landet vårt eget». Det vil bli lagt pekere til andre museumsutstillinger som ligger på nettet, og NMU håper $\mathrm{i}$ framtiden å kunne utlyse egne prosjektmidler til utvikling av nye utstillinger. Selv planlegger NMU en engelskspråklig presentasjon av den norske museumssektoren.

\section{Søk i museenes samlinger}

I PRIMUS-prosjektet som er omtalt ovenfor, arbeides det med en egen publikumsversjon for WWW. Norsk Folkemuseum har et samarbeid med Norges Tekniske Høgskole om et prosjekt for å legge ut kulturhistorisk dokumentasjonsfilm i 
26 database. I tillegg til materialet fra Universitetenes dokumentasjonsprosjekt ligger allerede også noen mindre museumssamlinger på nettet, og Sekretariatet for fotoregistrering (som fra 1.1.1997 er en del av NMU) vil tilrettelegge oversiktene over norske fotosamlinger og norske fotografer.

\section{Skoleveien til museene}

Barn og unge er en prioritert målgruppe i norsk kulturpolitikk, og det skal satses sterkere på opplæring i og bruk av informasjonsteknologi i skolen. Målet med «Skoleveien til museene» skal være at lærere og elever her skal kunne finne fram til relevante museumstilbud utfra faglige, aldersbestemte eller geografiske søkekriterier. Det kan være informasjon om undervisningsopplegg i museene, materiale som kan brukes til forberedelse eller etterarbeid i forbindelse med museumsbesøk, eller selvstendige nettpresentasjoner som er tilpasset skolens læreplaner. I startfasen er det gitt prosjekttilskudd til Norsk Teknisk Museum for å legge ut informasjon og veiledning til museets skoletilbud og til Paleontologisk museum ved Universitetet i Oslo for å lage en nettversjon av museets utstilling.

\section{Forskning og dokumentasjon}

Her er vi over på den delen av Museumsnett Norge der målgruppen primært er museumsansatte eller andre faglige samarbeidspartnere. I denne delen av nettet ønsker vi å presentere forskningsprosjekter som pågår i museene og oversikter over museenes spesialkompetanse. I startfasen vil vi knytte arbeidet til det nyetablerte Sekretariatet for samtidsforskning og samtidsdokumentasjon ved NMU og presen- tere en oversikt over museenes prosjekter innenfor dette feltet. Hovedmålet med denne delen av Museumsnett Norge skal være å bidra til sterkere faglig samarbeid og kontakt mellom museene og mellom museene og andre fagmiljøer. Vi vil også legge ut en kompetanseoversikt for naturhistorie som i dag foreligger i trykt versjon, og det vil bli arbeidet med en kompetanseoversikt innenfor konservering. NMU utga $i$ vår en museologisk bibliografi, og denne vil også bli lagt ut på nettet.

\section{Museumsfaglig informasjon}

Dette skal være porten for dem som søker informasjon fra NMU, andre fagorgan innenfor museumssektoren og museumsorganisasjonene. NMU tar sikte på å legge ut oversikt med elektronisk bestilling for alle publikasjoner, og måldokumenter, årsmeldinger og noen andre publikasjoner vil bli lagt ut i full tekst. Videre vil NMU legge ut informasjon om og skjemaer for søknad om prosjektmidler, og det vil bli vurdert å lage en elektronisk versjon av "Museumshåndboka». Organisasjonene vil få tilbud om å legge ut informasjonssider og få muligheter for elektronisk presentasjon av «Museumsnytt» og andre publikasjoner.

\section{Veien videre ut}

Veien videre skal ha pekere til annen nettinformasjon som har relevans for museer, som for eksempel materiale fra arkiv- og biblioteksektoren, og dette skal være veien å gå for de brukere som ønsker å finne fram til relevant informasjon om og fra museer utenfor Norge.

For NMU er det også viktig å se satsingen på Museumsnett Norge i sammenheng 
med de andre museumsutfordringene innenfor informasjonsteknologi. For å ivareta dette perspektivet og for å sikre en sterk faglig diskusjon rundt NMUs framtidige satsinger på hele denne sektoren, er det oppnevnt en egen styringsgruppe for IT-området. Prosjektstyret skal planlegge, prioritere og koordinere NMUs satsing innenfor dokumentasjon og EDB-utvikling og foreta autorisering av standarder for katalogisering og klassifikasjon.

Ambisjonene er store, og resultatet vil være avhengig av hvilke midler som kan stilles til rådighet for prosjektet, men først og fremst av hvordan satsingen vil prioriteres og følges opp i museene. Det er derfor en viktig utfordring å forankre et ansvar både $\mathrm{i}$ de offentlige forvaltningsorganene som har ansvar på museumssektoren, og i ledelsen ved de enkelte institusjonene.

Museer som tar sikte på å ha nasjonale eller regionale funksjoner må også ha et ansvar for å gi både publikum og fagkolleger over hele landet eller hele regionen muligheter til å gjøre seg kjent med museets samlinger og likedan at de må ta et formidlingsansvar som går lenger enn til bare å nå de gruppene som selv kan avlegge museet et fysisk besøk. Det er også naturlig at nasjonale museer tar et ansvar for fellesskapet med å ligge i forkant i utviklingen og ikke minst ta en vesentlig del av den belastningen som ligger i prøving og feiling når ny teknologi skal tas i bruk.

«Film er best på kino» heter det i et kjent norsk slagord. Fra museumshold vil vi på samme måte kunne hevde at kunst er best i original eller at gjenstander bør oppleves tredimensjonale. Samtidig er det klart at de museene som klarer å lage gode elektroniske formidlingstiltak på nettet, vil kunne nå et langt bredere publikum enn de musene som nøyer seg med den delen av publikum som har anledning til fysisk tilstedeværelse i museet. Selv er jeg ikke redd for at tilgang til "museumsopplevelser" på nettet skal svekke interessen for å oppsøke «originalene» i museene. Hvis et slikt resonnement skulle ha noe for seg, burde man sett tilsvarende virkninger av prospektkort og kunstbøker. Opplevelsen av å stå foran et originalt materiale har kvaliteter som det er vanskelig å beskrive, men det er kvaliteter som ingen kopi eller annen gjengivelse kan erstatte. Hvis museene klarer å møte ITutfordringene med gode nettilbud, vil vi i framtiden også få større trafikk gjennom museenes fysiske inngangsdører.

I 1984 hørte jeg et foredrag av Robert Chenall, en av de amerikanske pionerene innenfor bruk av informasjonsteknologi i museene. Foredraget hadde tittelen: What makes a system succsessful? Hans svar var klart og enkelt at oppdragsgiverne vet hva de ønsker å bruke det til, og hva de vil oppnå.

Dette er et råd som stadig er aktuelt! Vi går en spennende tid i møte!

\section{LITTERATUR}

Datatjenester og datasamarbeid mellom kunst-og kulturhistoriske museer. NAVFs EDB-senter for humanistisk forskning. Bergen 1979.

Den norske IT-veien. Bit for bit. Rapport fra statssekretærutvalget for IT. Samferdselsdepartementet, Oslo 1996.

Informasjonsteknologi $i$ museene 1995. Norske Kunst- og Kulturhistoriske Museer. Oslo 1995. $E D B$ i arkiv, bibliotek og museer. Rapport fra seminar i Asker 26.-27. november 1992. Oslo 1993. 
EDB-registrering av materiale ved de naturbistoriske museene. Seminarrapport. Norsk museumsutvikling 1994.

Museum. Mangfald, minne, motestad. NOU 1996:7. Kulturdepartementet. Oslo 1996.

Rapport fra proveprosjekt med EDB ved Norsk Folkemuseum. NAVFs EDB-senter for humanistisk forskning. Bergen 1979.

Skape bevare formidle. Handlingsplan for IT pa kulturområdet 1998-2001. Kulturdepartementet. Oslo 1997.

Skape bevare formidle. Grunnlagsmateriale for en ITplan for kultursektoren. Kulturdepartementet. Oslo 1996.

\section{NOTER}

1. Nå Humanistisk datasenter ved Universitetet i Bergen.

2. Norsk museumsutvikling (NMU) er det statlige fagkontoret for museer, opprettet av Stortinget fra 1.1.1994.

\section{SUMMARY}

About the use of computer technology in Norwegian museums

In this article the author gives a short survey of the development of information technology in Norwegian museums from the beginning of the 1970 s, and goes on to indicate the main challenges in this field today.

In 1979 the NKKM (The Union of Norwegian Art and Cultural Museums) submitted a standard catalogue card for the registration of objects of cultural history. Thanks to the strong commitment of the NKKM we have common development projects and common standards where consideration was also taken to smaller institutions. Currently there are 150 museums of cultural history and other institutions using the system for registration develo- ped at The Norwegian Computing Centre for the Humanities, Bergen. Some museums, however, have chosen to work out their own solutions.

More than $30 \%$ of the Norwegian population now have access to Internet - at home, at their work or at school. It is a considerable challenge for the museums to make use of this communication technology in order to reach new user groups, not least among children and youngsters. Earlier the museums have primarily been occupied with presenting electronic reference catalogues; now the chief challenge lies in communicating knowledge and experiences based on the collections and knowledge of the museums themselves. The Ministry of Culture has taken the initiative by creating an electronic network of information through Cultural Network Norway, of which Museum Network Norway will be an integral sector network.

Jon Birger Østby er sivilingenior med tilleggsutdanning $i$ etnologi og folkeminnevitenskap. Han er direktor for Norsk museumsutvikling. Adr: Nork museumsutvikling, Ullevålsveien 11, N-0165 Oslo.

Faks: + 4722110074

E-post: jonbirgero@nomusu.no 